\title{
A Comparison of Linear and Nonlinear Models in Forecasting Market Risk: The Evidence from Turkish Derivative Exchange
}

\author{
*Yasemin Deniz Akarım, Soner Akkoc \\ Dumlupınar University, Department of Banking and Finance, Turkey \\ *denizkoc12@gmail.com
}

\begin{abstract}
This paper aims to compare the volatility forecasting performance of linear and nonlinear models for ISE-30 future index which is traded in Turkish Derivatives Exchangefor the period between 04.02.2005-17.06.2011. As a result of analyses, we conclude that ANN model has better forecasting performance than traditional ARCH-GARCH models. This result is important in many fields of finance such as investment decisions, asset pricing, portfolio allocation and risk management
\end{abstract}

Keywords: Volatility Forecasting, ARCH-GARCH Models, Artifical Neural Network, Turkish Derivative Exchange

\section{Introduction}

Volatility is defined as the fluctations in security prices. As a barometer of the market risk, volatility is important for investment decisions, asset pricing, portfolio allocation and risk management in finance. In this respect, it is crucial to forecast volatility accurately in finance literature. Associated with the increasing importance of volatility, different volatility models come into use in the finance literature. Conditional heteroscedasticity models are the most commonly used volatility models in forecasting financial assets' volatility. In volatility forecasting, in addition to Engle's (1982) Autoregressive Conditional Heteroscedasticity Model (henceforth ARCH) and Bollerslev's (1986) Generalized Autoregressive Heteroscedasticity Model (henceforth GARCH), Artifical Neural Network (henceforth ANN)model is being used in the literature.ANN model which simply mimics the human brain function is successful in the estimation of the stock price behaviour due to its feature of learning from tha data. Model is working with multiple variables, easy adaptation to the noisy data and handling complex and nonlinear problems (Karaatl etal. (2005); Cinko and Avcl (2007). The paper aims to compare the performance of linear and nonlinear models in forecasting the volatility of ISE-30 future contracts which is traded in Turkish Derivatives Exchange. Future markets are important in terms of reducing the uncertainty about the future, forecasting the future values of prices and interest rates, providing efficienct risk management and supporting the spot markets. In the literatüre, the papers mostly focus on comparing forecasting performance of volatility models in spot markets. Different from the existing literature, this paper focus on forecasting volatility in future markets. Therefore, the findings of paper will contribute to the existing literature. The paper organized as follows section 2 summarise the literature, section 3 describes the methodology used, section 4 explains the dataset used, section 5 explain and interpret the emprical findings and section 6 concludes.

\section{Literature Review}

There is a large literature on forecasting volatility in financial markets. While some papers model the volatility of stock market indices (French et al., 1987; Feinstein, 1987; Schwert, 1989; Yllmaz, 1997; Gökçe, 2001; Balaban et al., 2003; Patev and Kanaryan, 2003; Mazıbaş, 2005; Mala \& Reddy, 2007) and some of them compare the volatility of stock markets of emerging and developed countries (Santis \& Imrohoroglu, 1997; Bekaert \& Harvey, 1997; Sevil \& Yalama, 2008). Also some papers analyse whether volatility forecasting is different in crisis period (Zadra, 1988; Schwert, 1989a; Schwert, 1990; Schwert 1998; Chaudhuri \& Klaassen, 2001; Patev \& Kanaryan, 2003; Law, 2006; Celikkol et al., 2010). In the literature, researchers usevariousmodelsto generate volatility forecasts such as traditional ARCH-GARCH models, asymmetric volatility models, stochastic volatility models, realized volatility models and ANN models Brailsford and Faff (1996); Cao and Tsay (1992); Franses and Dijk (1996); Ederington and Guan(2004); Bakır and Candemir (1997); Balaban (1999); Okay (1998); Yavan andAybar (1998). While Yalçın (2006); Bildiricietal. (2007); Mazıbaş (2005); Akar (2007) investigate the performance of ARCHGARCH volatility models, (Yumlu et al., 2005; Egeli et al., 2003; Lim \& McNelis, 1998) forecast the 
volatility by applying ANN models. ANN model is one of the important models which is used in forecasting of the financial variables such as stock price, foreign exchange rate, inflation rate, interest rate and volatility. White (1988), is the first who applies ANN model on financial data, tests the efficient market hypothesis by modelling the daily return series of IBM with ANN model. Following White(1988), (Yoon \& Swales, 1990; Hassan et al., 2006; Boyd et al., 1996; Tsibouris \& Zeidenberg, 1995) forecast the stock prices by applying ANN model and they conclude that financial market are not efficient. Lawrance (1997) ; Van Eyden (1996) ; Kimoto et al. (1990); Fernandez-Rodriguez etal. (2000) ;Phua et al. (2000);Yao and Tan (2000); Lim and McNelis (1998) forecast index return by applying ANN model in stock exchange of Johannesberg,Tokyo, Singapore, Malaysia and Australia, respectively.In addition to these papers, by using ANN model, (Versace et al., 2004; Vashisth \& Chandra, 2010; Kwong, 2001) forecast the stock returns of 30-companies in Dow Jones index, Nifty index return, seven Australian companies, Saudi Arabia companies in various sectors, respectively.

In Turkey,(Egeli et al., 2003; Diler, 2003; Cinko \& Avcl, 2007; Yıldız et al., 2008) forecast different indices in Istanbul Stock Exchange by using ANN model. Dutta andShekhar (1988); Moody and Utans (1991); Surkan andSingleton(1991); Kimetal.(1993); Maher andSen (1997) make risk assessment of fixed income securities by employing ANN model. Recently, it is possible to find different papers that compare the performance of ANN model and traditional models in forecasting financial data. Boyd etal. (1996) find that ARIMA modelis superior to ANN model in forecasting commodity prices. Chiang et al. (1996) conclude that traditional statistical methods are better than ANN model in forecasting the end of year value of mutual funds. Dutta and Shekhar (1988) find that ANN model is more successful in rating and pricing bonds. Yoon and Swales (1990) conlude that ANN model has better performance than discriminant analysis in forecasting stock prices. Altay and Satman (2005) state that linear regression model has better forecasting performance than ANN model in ISE-30 and ISE-100 indices. Karaatll etal. (2005) find that ANN model is superior to the linear regression model in forecasting of ISE-100 index. Cinko and Avcr (2007) indicate that ANN model is more successful than linear regression model in daily and seasonal forecasting of ISE-100 index. Dunis et al. (2012) find that ANN model is superior to the traditional ARMA model in forecasting EUR/USD exchange rate during the financial crisis of 20072009.Additionally, Lim and McNelis (1998); Schittenkopf, et al. (1998); Hu and Tsoukalas (1999);Schittenkopf et al. (2000); Bartlmae and Rauscher (2000);Egeli et al. (2003); Yumlu etal. (2005); Hamid and Iqbal (2004);Nakamura (2005); Xiao et al. (2008); Kadılar et al. (2009); Dhar etal. (2010); Xu and Liu (2011) compare the performance of traditional ARCH-GARCH models and ANN model and conclude that ANN model has better performance than traditional ARCH-GARCH models. Different from these papers, Mantri etal.(2010), Anwar and Mikami (2011) state that ARCH-GARCH models are superior to ANN model.

\section{Methodology}

Linear Models: In linear models, we firstlyuse AR, MA, ARMA model to identify the best fitted model in modelling conditional mean. AR model assumes that a time series is explained by its lagged values or an error term. A simple AR(p) model is given in Equation (1).

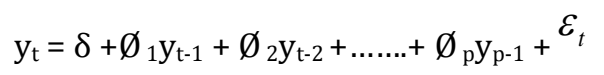

In equation (1), $\mathrm{y}_{\mathrm{t}}$ denotes a time series, ${ }^{\varepsilon_{t}}$ denotes error term. MA model is a function of the lag values of error term and unpredictable error term. MA model is given in Equation (2).

$$
\mathrm{y}_{\mathrm{t}}=\mu+{ }_{t}+\theta_{1} \varepsilon_{t-1+\theta_{2}} \varepsilon_{t-2}+\ldots \ldots+\theta_{\mathrm{q}} \varepsilon_{t-\mathrm{q}}
$$

ARMA models are a combination of AR and MA models. An ARMA model predicts a value in a response time series as a linear combination of its own past values and past errors and defined as in Equation (3) (Enders, 2004) :

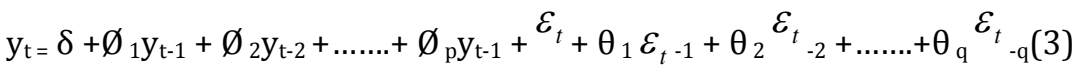

After identification of appropriate ARMA model, it is necessary to examine whether time series include Autoregressive Conditional Heteroscedasticity. In the literature, the most suggested models to test the existence of ARCH effect is Engle's (1982) ARCH-LM test and McLeod and Li's (1983) Q test. Therefore we apply ARCH LM test (Lagrange Multiplier, LM) to investigate the presence of Autoregressive Conditional Heteroscedasticity effect in residuals of ARMA model under the null hypothesis of no ARCH effects. 
ARCH-LM test suggested by Engle is applied by getting the residual from the equation (4), square them ( $\varepsilon_{t 2}$ ) and model them as a dependent variable in equation (5).

$$
\begin{aligned}
& \mathrm{y}_{\mathrm{t}}=\delta+\emptyset_{1 \mathrm{y}_{\mathrm{t}-1}}+\emptyset_{2 \mathrm{y}_{\mathrm{t}-2}}+\ldots \ldots . .+\emptyset_{\mathrm{p} \mathrm{y}_{\mathrm{p}-1}+} \varepsilon_{t} \\
& \varepsilon_{t 2}=\delta+\alpha_{1} \varepsilon_{\mathrm{t}-1}^{2}+\alpha_{2} \varepsilon_{\mathrm{t}-2}^{2}+\ldots \ldots .+\alpha_{\mathrm{q}} \varepsilon_{\mathrm{t}-\mathrm{q}}^{2}+v_{t}
\end{aligned}
$$

As the ARCH effect is detectedin stock exchange indices, the volatilityis modelled by using ARCH-GARCH models. ARCH model which is suggested by Engle (1982) assumes that the variance of " $u$ " at time $t, \sigma_{t}{ }^{2}$ depends on the square of error term, $\mathrm{u}^{2}(\mathrm{t}-1)$ at time $\mathrm{t}-1$.

In this context, $\operatorname{ARCH}(q)$ and $\operatorname{GARCH}(q, p)$ models are given in Equation (6),

$$
\begin{aligned}
& \alpha_{0}>0, \quad \alpha_{i} \geq 0 \\
& h_{t} \alpha_{0}+\alpha_{1} \varepsilon_{t-1}{ }^{2}+\alpha_{2} \varepsilon_{t-2}{ }^{2}+\ldots . .+\alpha_{q} \varepsilon_{t-q}{ }^{2}+\mathrm{v}_{\mathrm{t}}
\end{aligned}
$$

GARCH models which is the generalized version of ARCH models are introduced by Engle (1982) and Bollerslev (1986). GARCH models include conditional variance equation in addition to conditional mean equation. GARCH model can be defined as in Equation (7).

$$
h_{t}=\alpha_{0}+\sum_{i=1}^{q} \alpha_{i} r^{2}{ }_{t-i}+\sum_{j=1}^{p} \beta_{j} h_{t-j}
$$

restrictions of the model are as follows:

variance

$$
\begin{aligned}
& \alpha_{i} \geq 0 \\
& \beta \mathrm{j} \geq 0 \\
& \alpha i_{+} \beta_{\mathrm{j}} \leq 1
\end{aligned}
$$

Artificial Neural Networks: ANN is a flexible non-linear modeling tool. The human being's learning ability is transferred to a computer environment with ANN. ANN is composed of a number of processing elements, which come together within the frame of particular rules which are called neurons or nodes (Haykin, 1994; Zhang et al., 1998). An ANN generally consists of three layers of interconnected neurons. A three layer ANN is shown in Fig. 1. The first layer is called the input layer where external information is received. Each neuron in the input layer sends signals to the hidden layer. Information received from the input layer is processed in the hidden layer. The output layer transmits the information outside of the network.

Figure 1: A three layer ANN

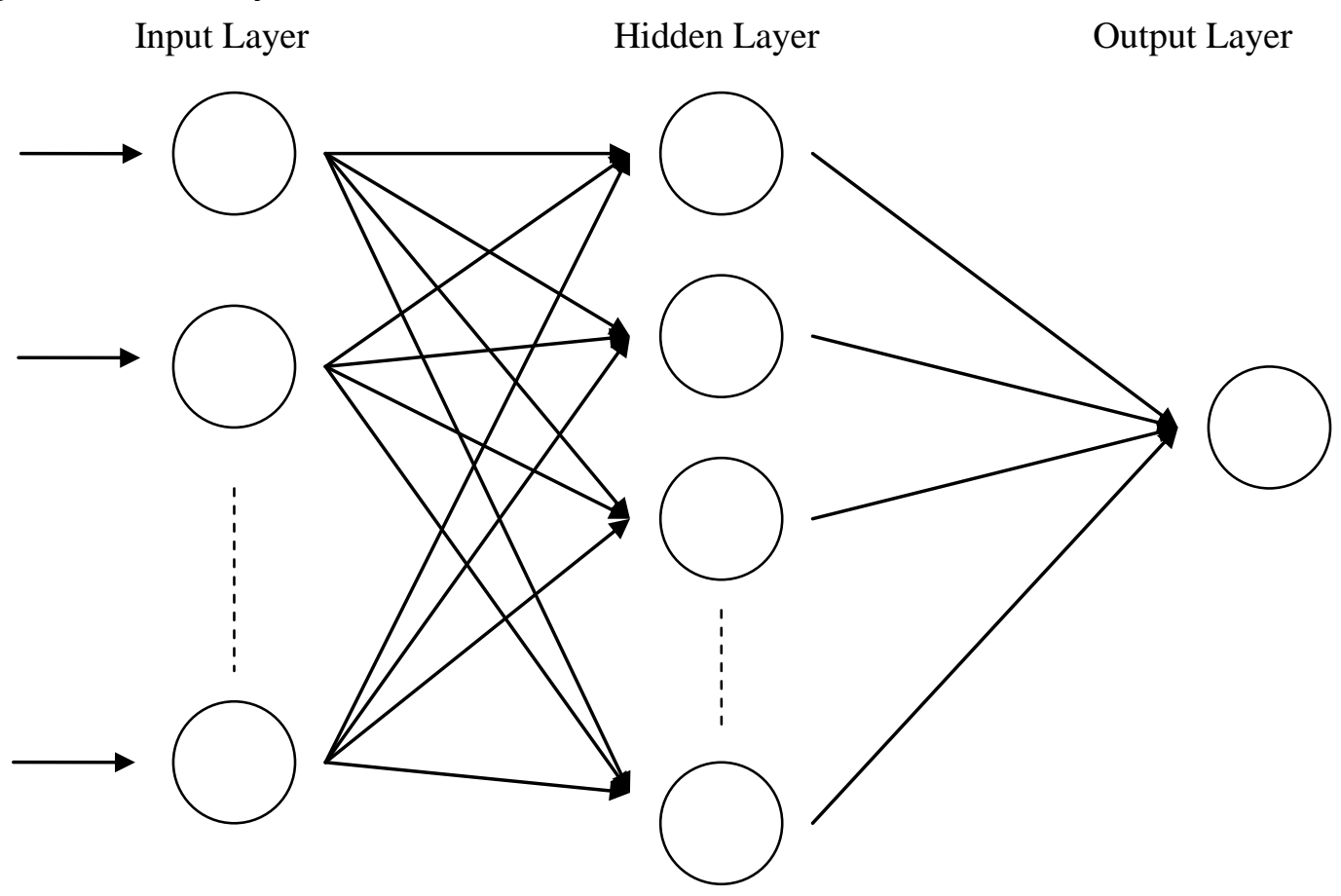


Although ANN can be applied successfully in many fields, it has some disadvantages. ANN requires a long training process in developing the optimal model. ANN has also been criticized for lack of theory. There is no opportunity to explain the result produced by ANN, in other words, the model acts as a black box (Chen and Huang 2003; Piramuthu, 1999; Trippi and Turban 1996; West, 2000).

Data: The dataset includes the closing prices of ISE-30 future index, which is traded in Turkish Derivatives Exchange, for the period between 04.02.2005-17.06.2011 providing 1606 observations. Return series of ISE-30 index futures are calculated as in Equation(11). $\mathrm{P}_{\mathrm{t}}$ denotes the closing price of ISE30 index futures at time, $\mathrm{t}$.

$$
R_{t}=\ln \left(\frac{P_{t}}{P_{t-1}}\right)
$$

\section{Results}

ARCH-GARCH Model: The summary statistics of the return series are given in Table.1. The mean return and standard deviation of ISE-30 index futures are 0.000469 and 0.020123 , respectively. According to the skewness and kurtosis values, it is clear that ISE-30 future index return do not have normal distribution.

Table 1: Summary Statistics

\begin{tabular}{lllllll}
\hline Mean & Median & Maximum & Minimum & Std. Dev. & Skewness & Kurtosis \\
\hline 0.000469 & 0.000442 & 0.096570 & -0.099722 & 0.020123 & -0.070025 & 5.725247 \\
\hline
\end{tabular}

Table 2: ADF Unit Root Test Results

\begin{tabular}{|c|c|c|c|c|}
\hline Variable & \multicolumn{2}{|c|}{ ADF- $t$ statistics-Without trend } & \multicolumn{2}{|c|}{ ADF- t statisticsWith trend } \\
\hline ISE-30 Future Index Return & \multicolumn{2}{|c|}{$-38.2096(0.0000)$} & \multicolumn{2}{|c|}{$-38.1978(0.0000)$} \\
\hline \multicolumn{5}{|c|}{$\begin{array}{l}\text { MacKinnon critical values at } 1 \%, 5 \% \text { ve } 10 \% \text { significance level are }-3.43,-2.86,-2.56 \text {, respectiv } \\
\text { untrended model and }-3,96,-3.41,-3.12 \text {, respectively for trended model. }\end{array}$} \\
\hline \multicolumn{5}{|c|}{$\begin{array}{l}\text { We investigate the stationary of the return series by using Augmented Dickey-Fuller unit roc } \\
\text { According to the findings in Table.2, t-values are greater than } 1 \%, 5 \% \text { and } 10 \% \text { critical values for tr } \\
\text { and untrended models. Therefore, we reject the null hypothesis of "series have unit root" and co } \\
\text { that return series are stationary. For this reason, we use return series in the subsequent analysis. }\end{array}$} \\
\hline \multicolumn{5}{|c|}{ Table 3: Results of ARIMA Model } \\
\hline Variable & Coefficient & Std. Error & t-Statistic & Prob. \\
\hline $\operatorname{AR}(1)$ & -0.7697 & 0.2666 & -2.8873 & 0.0039 \\
\hline MA(1) & 0.8196 & 0.2670 & 3.0689 & 0.0022 \\
\hline $\mathrm{MA}(2)$ & 0.0566 & 0.0252 & 2.2433 & 0.0250 \\
\hline
\end{tabular}

After testing the stationary of return series, we use Autocorrelation Function (henceforth ACF) and Partial Autocorrelation Function (henceforth PACF) to identify the best fitted ARMA model. In addition to ACF and PACF functions, we also use Akaike and Schwarz criterion to determine the appropriate ARIMA model. The appropriate ARIMA models are presented in Table 3.

Table 4: ARCH-LM Test

\begin{tabular}{lllc}
\hline F-statistic & Prob. F & Obs*R-squared & Prob. Chi-Square \\
\hline 28.9770 & 0.0000 & 28.4975 & 0.0000 \\
\hline
\end{tabular}

The next stage is to test the existence of ARCH effects in residuals by using ARCH-LM test. According to the findings in Table.4, prob values of F-statistic is less than 0.05 and so we reject the null hypothesis. This finding supports the presence of ARCH effect in residuals and consequently we use ARCH model to model volatility in ISE-30 future index.The best ARCH model for ISE-30 index futures is summarized in Table 5. 
Table 5: The Results of ARCH-GARCH Model Estimations

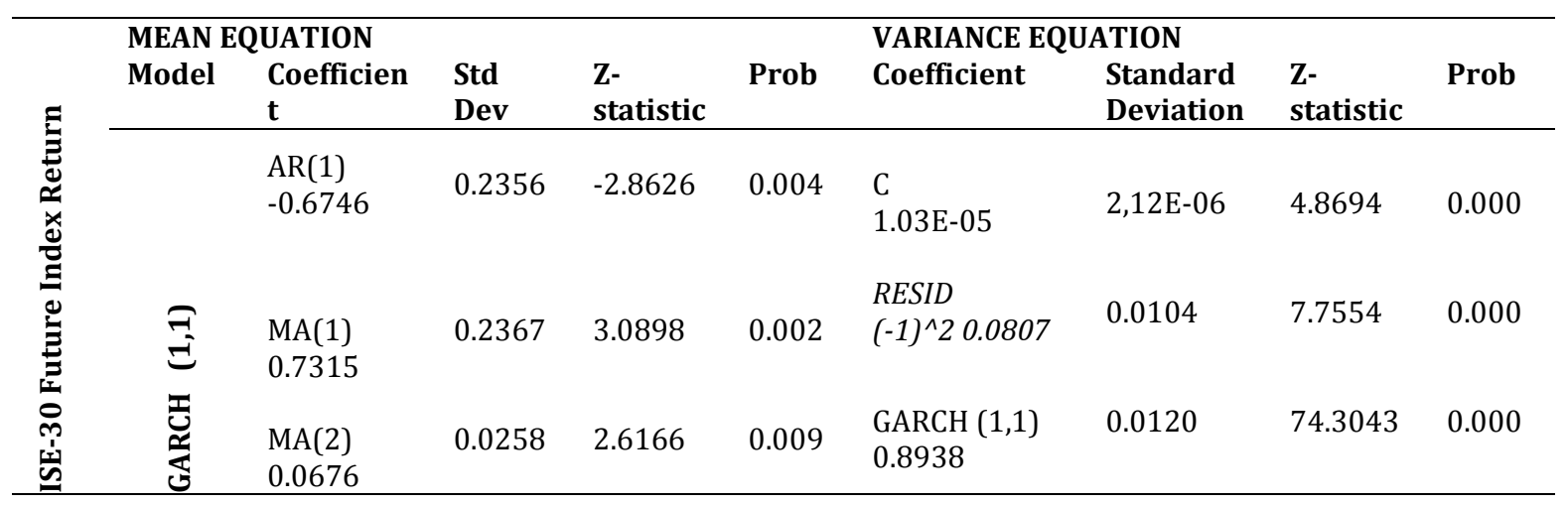

ANN Model: We built 4 different network architectures by using 3 time lags, 5 time lags, 7 time lags and 9 time lags. Because we obtain the best result from the 5 time lags model, we have just reported this model's results. Since Vellido et al., (1999) point out that more than $75 \%$ of business applications using ANN will adopt the BPN training algorithm; this study also uses the feed forward multilayer perceptrons with the BPN training algorithm. As recommended by Zhang et al., (1998) the single hidden layer network is sufficient to model any complex system, therefore, the designed network will have only one hidden layer. Egeli et al., (2003) also report that 1 hidden layer is better than 2, 3 and 4 hidden layer in modeling of the Istanbul Stock Exchange. Generally, the learning rate is set between 0.01 and 0.4 , the momentum is set between 0.8 and 0.99 and the training lengths ranging from 1000 to 10000 epochs (Chuang and Lin, 2009). Determining the number of hidden nodes is generally associated with input nodes. The most commonly used way in determining the number of hidden nodes is via experiments or trial and error process. The number of hidden nodes to be tested $2 n, 2 n \pm 1$ and $2 n \pm 2$, n denotes input nodes (HechtNielsen, 1990). To determine the optimal number of hidden nodes, for 5 time lags network structure, 8,9 , $10,11,12$ was tested, when the learning rate, momentum and training epochs are set to $0.1,0.9$ and 2,000, respectively. In other words, we develop 5 different models for this purpose.

Table 6: Result of 5 Time Lags Network Structure with Various Hidden Nodes

\begin{tabular}{ll}
\hline Architecture & Mean Absolute Error (MAE) \\
\hline $5-8-1$ & 3.5795 \\
$5-9-1$ & 3.9832 \\
$5-10-1$ & $3.5296^{*}$ \\
$5-11-1$ & 3.8752 \\
$5-12-1$ & 3.9520 \\
\hline
\end{tabular}

*Best network architecture Note: The numbers in Table 6 are multiplied by $10^{4}$.

Table 7: MAE of Various Learning Parameters for the 5-10-1 Architecture

\begin{tabular}{lllll}
\hline $\begin{array}{l}\text { Learning } \\
\text { rate }\end{array}$ & \multicolumn{4}{l}{ Momentum Rate } \\
\hline 0.001 & $\mathbf{0 . 7}$ & $\mathbf{0 . 8}$ & $\mathbf{0 . 9}$ & $\mathbf{0 . 9 9}$ \\
0.005 & 3.6187 & 3.7028 & 3.6588 & 3.6582 \\
0.01 & 3.5920 & 3.5810 & 3.5810 & 3.6182 \\
0.05 & 3.5726 & 3.5724 & 3.5597 & 3.6002 \\
0.1 & 3.5376 & 3.5595 & 3.5296 & 3.6234 \\
0.2 & 3.5393 & 3.5409 & 3.5583 & 3.6593 \\
0.3 & 3.5417 & 3.5318 & 3.5601 & 3.7015 \\
0.4 & 3.5343 & 3.5564 & 3.5684 & 3.7055 \\
0.5 & $3.5065^{*}$ & 3.5639 & 3.6240 & 3.7045 \\
\hline
\end{tabular}

*Best network architecture Note: The numbers in Table 7 are multiplied by $10^{4}$. 
The MAE of the 5 time lags ANN model is shown in Table 6. The network architecture with the lowest MAE (5-10-1) is considered as the optimal network architecture. After determining the optimal network architecture, various learning parameters are applied on this architecture. Nine different learning rates (from 0.001 to 0.5 ) and four different momentum rates (from 0.7 to 0.99 ) have been tested, so here we have also developed 36 different models. The MAE of various learning parameters for the 5-10-1 architecture is shown in Table 7. The minimum MAE of the 5 time lags ANN model is 0.000350652 when the learning rate and momentum are set to 0.5 and 0.7 respectively. ${ }^{1}$

Table 8: The Comparison of Forecasting Performance

\begin{tabular}{ll} 
Model & MAE \\
\hline GARCH $(1,1)$ & 4.2578 \\
ANN & 3.5065 \\
\hline Note:The numbers in Table 8 are multiplied by $10^{4}$.
\end{tabular}

Note:The numbers in Table 8 are multiplied by $10^{4}$.

According to the Table.8, while the MAE value of the traditional GARCH $(1,1)$ model is 0,00042 , the MAE value of ANN model equals to 0.00035 . This finding shows that ANN model has lower MAE values than GARCH $(1,1)$ model. Therefore we conclude that ANN model has better performance than GARCH $(1,1)$ model in forecasting volatility.

\section{Conclusion}

Volatility is sudden movements in stocks price levels and high volatility in stock markets affects investment decisions directly.Market participants consider especially high volatile markets to increase gain from investment. Therefore different volatility models and that's performance have become important for investors. In this paper, we forecast the volatility of ISE-30 future index return by applying ARCH-GARCH models and ANN model and compare the relative performance of models according to their MAE values. The findings of the paper support that ANN model, which represents the nonlinear models, has better forecasting performance than traditional ARCH-GARCH models. This result is consistent with those of Lim and McNelis (1998); Schittenkopf et al., (1998); Hu andTsoukalas (1999); Schittenkopf et al. (2000); Bartlmae and Rauscher (2000); Egeli et al. (2003); Yumlu et al. (2005); Hamid and Iqbal (2004);Nakamura (2005); Xiao et.al. (2008); Kadılar et al. (2009); Dhar et al. (2010); Xu and Liu (2011). In conclusion, volatility forecasting is important for many financial applications such asinvestment, asset pricing, portfolio allocation and risk management. From this perspective, the findings of the paper is important for market participants since they can increase the success of their financial decisions by using ANN model in forecasting market risk.

\section{References}

Anwar, S. \& Mikami, Y. (2011). Comparing Accuracy Performance of ANN,MLR, and GARCH Model in Predicting Time Deposit Return of Islamic Bank. International Journal of Trade Economics and Finance, 2 (1), 44-51.

Akar, C. (2007). Volatilite Modellerinin Öngörü Performansları: Arch, Garch ve Swarch Karşılaștırması. Isletme Fakültesi Dergisi, 8(2), 201-217

Altay, E. \& Satman, M. H. (2005). Stock Market Forecasting: Artificial Neural Networks and Linear Regression Comparison in an Emerging Market. Journal of Financial Management and Analysis, 18 (2), 18-33.

Bakır, H. \& Candemir,H. B. (1997). Menkul Kıymet Getirilerinin Şartlı Varyans Modelleri: IMKB için Bir Uygulama, Sermaye Piyasası Kurulu Yayınları, Ankara.

Balaban, E. (1999). Forecasting Stock Market Volatility: Evidence from Turkey, The ISE Finance Award Series.1., presented in International Conferences in Economics at the Middle East Technical University.

\footnotetext{
${ }^{1}$ The minimum MAE of the 3 time lags model, the 7 time lags model and the 9 time lags model are $0.000367177,0.000377315$, and 0.00036909 , respectively.
} 
Balaban, E., Bayar, A. \& Faff, R. (2003). Forecasting Stock Market Volatility:Evidence From Fourteen Countries, Center for Financial Markets Research Working PaperNo. 02.04, EFMA Helsinki Meetings.

Bartlmae, K. \& Rauscher, F. A. (2000). Measuring DAX Market Risk: A Neural Network Volatility Mixture Approach, http://ukpmc.ac.uk/abstract/CIT/436614

Bekaert, G. \& Harvey, C. R. (1997). Emerging Equity Market Volatility. Journal of Financial Economics, 43 (1), 29-77

Bildirici, M., Oktay, S. \& Aykaç, E. (2007). IMKB'de Getiri Değişkenliğinin Hesaplanmasında ARCH/GARCH Ailesi Modellerin Kullanılması, Türkiye Ekonometri ve İstatistik Kongresi,İnönü Üniversitesi Malatya.

Bollerslev, T. (1986). Generalized Autoregressive Conditional Heteroscedasticity. Journal of Econometrics, 31, 307-327.

Boyd, K., Nowrouz, M. S., Kermanshahib, B. \& Kaastrac, I. (1996). A Comparison of Artificial Neural Network and Time Series. Models For Forecasting Commodity Prices, 10(2), 169-181

Brailsford, T. J. \& Faff, R. W. (1996). An Evaluation of Volatility Forecasting Techniques. Journal of Banking and Finance, 20, 419-438.

Cao, C. Q. \& Tsay, R. S. (1992). Nonlinear Time Series Analysis of Stock Volatility. Journal of Applied Econometrics, 7 (1), 165-185.

Celikkol, H., Akkoc, S. \& Akarim, Y. D. (2010). The Impact of Bankruptcy of Lehman Brothers on the Volatility Structure of ISE-100 Price Index. Journal of Money, Investment and Banking, 18, 5-12

Chaudhuri, K. \& Klaassen, F. (2001). Have East Asian Stock Markets Calmed Down? Evidence From a Regime-Switching Model, Department of Economics Working Paper University of Amsterdam.

Chen, M. C. \& Huang, S. H. (2003). Credit Scoring And Rejected Instances Reassigning Through Evolutionary Computation Techniques. Expert Systems With Applications, 24, 433-441.

Chiang, W. C., Urban, T. L. \& Baldridge, G. W. (1996). A Neural Network Approach to Mutual Fund Net Asset Value Forecasting. Omega, 24, 205-215.

Chuang, C. L. \& Lin, R. H. (2009). Constructing a Reassigning Credit Scoring Model. Expert Systems With Applications, 36, 1685-1694.

Cinko, M. \& Avcl, E. (2007). A Comparision of Neural Network and Linear Regression Forecasts of The Ise100 Index. Marmara Üniversitesi Sosyal Bilimler Enstitüsü Dergisi, 7(28), 301-307

Dhar, J., Agrawal, P., Singhal, V., Singh, A. \& Murmu, R. K. (2010). Comparative Study of Volatility Forecasting Between ANN and Hybrid Models for Indian Market. International Research Journal of Finance and Economics, 45, 68-79.

Diler, A. I. (2003). ISE National-100 Index of the Direction of the Neural Network ErrosEstimation Method with Propagation Backward. ISE Review, 25(26), 65-81.

Dutta, S. \& Shekhar, S. (1988). Bond Rating: A Non-conservative Application of Neural Networks, in Proceedings of the IEEE International Conference on Neural Networks. IEEE Press, 2, 443-450.

Dunis, C. L., Laws, J. \& Schilling, U. (2012). Currency Trading in Volatile Markets: Did Neural Networks Outperform For The EUR/USD During The Financial Crisis 2007-2009? Journal of Derivatives and Hedge Funds, 18, 2-41.

Ederington, L. H. \& Guan, W. (2004). Forecasting Volatility,University of Oklahoma Working Paper.

Egeli, B., Ozturan, M. \& Badur, B. (2003). Stock Market Prediction Using Artificial Neural Networks, Proceedings of the 3rd Hawaii International Conference on Business, Hawai, USA.

Enders, W. (2004). Applied Econometric Time Series,Willey, United States of America.

Engle, R. F. (1982).Autoregressive Conditional Heteroscedasticity with Estimates of the Variance of United Kingdom Inflation. Econometrica, 50(4), 987-1008.

Feinstein, S. P. (1987). Stock Market Volatility. Federal Reserve Bank of Atlanta Economic Review, 2, 42-47.

Fernandez-Rodriguez, F., Gonzalez-Martel, C. \& Sosvilla-Rivero, S. (2000). On Profitability of Technical Trading Rules Based on Articial Neural Networks : Evidence from the Madrid Stock Market. Economic Letters, 69, 89-94

Franses, P. H. \& Dijk, D. V. (1996). Forecasting Stock Market Volatility Using (Non-Linear) Garch Models. Journal of Forecasting, 15(3), 229-235

French, K. R., Schwert, G. W. \& Stambaugh, R. F. (1987). Expected Stock Returns and Volatility. Journal of Financial Econometric, 19, 3-29

Gökçe, A. (2001). Istanbul Menkul Kıymetler Borsası Getirilerindeki Volatilitenin ARCH Teknikleri ile Ölçülmesi. Gazi Üniversitesi IIBF Yayını, 3(1).

Hamid, S. A. \& Iqbal, Z. (2004). Using Neural Networks for Forecasting Volatility of S\&P 500 Index Futures Prices. Journal of Business Research, 57(10), 1116-1125.

Haykin, S. (1994). Neural Networks : A Comprehensive Foundation, Prentice Hall Int. Inc., New Jersey. 
Hassan, R., Nath, B. \& Kirley, M. (2006). A Fusion Model of HMM, ANN and GA for Stock Market Forecasting. Expert Systems with Applications, 33(1), 171-180.

Hecht-Nielsen, R. (1990). Neurocomputing. Menlo Park, CA: Addison- Wesley.

Hu, M. Y. \& Tsoukalas, C. (1999). Combining Conditional Volatility Forecasts Using Neural Networks: An Application To The EMS Exchange Rates. Journal of International Financial Markets Institutions and Money, 9(4), 407-422

Kadılar, C., Simsek, M. \& Aladağ, Ç. H. (2009). Forecasting The Exchange Rate Series With ANN: The Case of Turkey. Ekonometri ve Istatistik,9, 17-29

Karaatlı, M., Güngör, İ., Demir, Y. \& Kalaycı, Ş. (2005). Hisse Senedi Fiyat Hareketlerinin Yapay Sinir Ağları Yöntemi ile Tahmin Edilmesi. Ballkesir Üniversitesi İIBF Dergisi, 2(1), 22-48.

Kim, J. W., Weistroffer, H. R. \& Redmond, R. T. (1993). Expert System for Bond Rating: A Comparative Analysis of Statistical, Rule-Based, and Neural Network Systems. Expert Systems,10(3), 167-171.

Kimoto, T., Asakawa, K., Yoda, M. \& Takeoka, M. (1990). Stock Market Prediction System With Modularneural Networks. International Joint Conference on Neural Networks, 1, 1-6.

Kwong, C. K. (2001). Financial Forecasting Using Neural Networks or Machine Learning Techniques, http://www.innovexpo.itee.uq.edu.au/2001/projects/s804018/index.html.

Law, S. H. (2006). Has Stock Market Volatility in the Kuala Lumpur Stock Exchange Returned to Pre-Asian Financial Crisis Levels? ASEAN Economic Bulletin, 23(2), 212-29.

Lawrence, R. (1997). Forecasting Stock Prices Using Neural Networks, Course Project University of Maritoba, Canada, 5-10.

Lim, G. C. \& Mcnelis, P. D. (1998).The Effect of the Nikkei and the S\&P on the All- Ordinaries: A Comparison of Three Models. International Journal of Finance and Economics, 3(3), 217-228.

Maher, J. J. \& Sen, T. K. (1997). Predicting Bond Ratings Using Neural Networks: A Comparison with Logistic Regression. International Journal of Intelligent Systems in Accounting, Finance and Management, 6(1), 59-72

Mala, R. \& Reddy, M. (2007). Measuring Stock Market Volatility in an Emerging Economy. International Research Journal of Finance and Economics, 8, 126-133.

Mantri, J. K., Gahan, P. \& Nayak, B. B. (2010). Artificial Neural Networks An Application to Stock Market Volatility. International Journal of Engineering Science and Technology, 2(5), 1451-1460

Mazıbaş, M. (2005). İMKB Piyasalarındaki Volatilitenin Modellenmesi ve Öngörülmesi: Asimetrik GARCH Modelleri ile bir Uygulama,VII. Ulusal Ekonometri ve İstatistik Sempozyumu, İstanbul Üniversitesi İktisat Fakültesi Ekonometri Bölümü.

McLeod, A. I. \& Li, W. K. (1983). Diagnostic Checking ARMA Time Series Models Using Squaredresidual Autocorrelations. Journal of Time Series Analysis, 4, 269-273.

Moody, J. \& Utans, J. (1991). Principled Architecture Selection for Neural Networks: Applications to Corporate Bond Rating Predictions, in NIPS 91 Advances in Neural Information Processing Systems, 4, J. E. Moody, S. J. Hanson, and R. P. Lippmann, ed., Morgan Kauffman, San Mateo : 683690.

Nakamura, E. (2005). Inflation Forecasting Using a Neural Network. Economics Letters Elsevier, 86(3), 373-378

Okay, N. (1998). Asymmetric Volatility Dynamics: Evidence from Istanbul Stock Exchange,Business and Economics for the 21st Century. Anthology, 2, 207-216.

Patev, P. \& Kanaryan, N. (2003). Stock Market Volatility Changes in Central Europe Caused by Asian and Russian Financial Crises-Stock Market Volatility Changes in Central Europe, Tsenov Academy of Economics Department of Finance and Credit Working Paper,No.03-01.

Phua, P. K. H., Ming, D. \& Lin, W. (2000). Neural Network with Genetic Algorithms for Stocks Prediction,Fifth Conference of the Association of Asian-Pacific Operations Research Societies,5th 7th July, Singapore

Piramuthu, S. (1999). Financial Credit-Risk Evaluation With Neural And Neurofuzzy Systems. European Journal of Operational Research, 112, 310-321.

Santis, D. G. \& Imrohoroglu, S. (1997). Stock Returns And Volatility inEmerging Financial Markets. Journal of International Money and Finance, 16, 561-579.

Schittenkopf, C., Dorffner, G. \& Dockner, E. J. (1998). Volatility Predictions With Mixture Density Networks,in ICANN 98, Proceedings of the 8th International Conference on artificial Neural Networks, L. Niklasson, M. Bodén and T. Ziemka, ed., Berlin : 929-934.

Schittenkopf, C., Dorffner, G. \& Dockner, E. J. (2000). Forecasting Time-Dependent Conditional Densities: A Semi-Nonparametric Neural Network Approach. Journal of Forecasting, 19(4), 355-374.

Schwert, G. W. (1989). Why Does Stock Market Volatility Change Over Time? Journal of Finance, 44, 11151153. 
Schwert, W. (1989a). Business Cycles, Financial Crises and Stock Volatility. Carnegie- Rochester Conference Series on Public Policy, 31, 83-126.

Schwert, W. (1998). Stock Market Volatility: Ten Years After The Crash. NBER Working Paper No. 6381.

Schwert, W. (1990). Stock Volatility and The Crash of 87. The Review of Financial Studies, 3(1), 77-102.

Sevil, G. \& Yalama, A. (2008). Forecasting World Stock Markets Volatility. International Research Journal of Finance and Economics, 15, 151- 166

Surkan, A. \& Singleton, J. (1991). Neural Networks for Bond Rating Improved by Multiple Hidden Layers. in Proceedings of the IEEE International Conference on Neural Networks, 2, 157-162.

Tsibouris, G. \& Zeidenberg, M. (1995). Neural Networks As An Alternative Stock Market Model,Neural Networks in the Capital Markets, John Wiley \& Sons.

Trippi, R. R. \& Turban, E. (1996). Neural Networks in Finance and Investing, Chicago:Irwin Professional Pub.

Xiao, W., Fei, Q. \& Chen, W. (2008). Forecasting Chinese Stock Markets Volatility Based on Neural Network Combining. International Conference on Natural Computation, 7, 3-27.

$\mathrm{Xu}$, J. \& Liu, J. (2011). Forecasting Volatility of Chinese Composite Index Based on Empirical Mode Decomposition and Neural Network, International Conference on Economics and Finance Research IPEDR.

West, D. (2000). Neural Network Credit Scoring Models. Computers and Operations Research, 27, 11311152.

White, H. (1988). Economic Prediction Using Neural Networks: The Case of UBM Daily Stock Returns. Proceedings of the IEEE International Conference on Neural Networks, 451-458.

Van-Eyden, R. J. (1996).The Application of Neural Networks in the Forecastingof Share Prices, 1st Edn. Finance and Technology Publishing, Virginia, ISBN : 0965133203

Vashisth, R. \& Chandra, A. (2010). Predicting Stcok Returns in Nifty Index: An Application of Artificial Neural Network. International Research Journal of Finance and Economics, 49, 15-23.

Vellido, A., Lisboa, P. J. G. \& Vaughan, J. (1999). Neural Networks İn Business: A Survey of Applications (1992-1998). Expert Systems with Applications, 17, 51-70.

Versace, M., Bhatt, R., Hinds O. \& Shiffer, M. (2004). Predicting The Exchange Traded Fund DIA With A Combination of Genetic Algorithms and Neural Networks. Expert Systems Applications, 27, 417-425

Yalçın, Y. (2006). Stokastik Oynaklık Modeli İle İstanbul Menkul Kıymetler Borsasında Kaldıraç Etkisinin Incelenmesi, 10. Ulusal Finans Sempozyumu 01-04 Kasım, İzmir.

Yao, J. \& Tan, C. L. (2000). A Case Study On Using Neural Networks To Perform Technical Forecasting of Forex. Neurocomputing, 34, 79-98.

Yavan, Z. A. \& Aybar, C. B. (1998). IMKB'de Oynaklık. IMKB Dergisi, 2(6), 35-47.

Ylldız, B., Yalama, A. \& Coskun, M. (2008). Forecasting The Istanbul Stock Exchange National 100 Index Using an Artificial Neural Network,World Academy of Science. Engineering and Technology, 46, 3639.

Yılmaz, M. K. (1997). Hisse Senedi Fiyat Oynaklı̆̆ı ve Fiyat Oynaklığının Vade Yapısı: Türkiye için Genel Bir Değerlendirme. IMKB Dergisi, 1(3), 25-45

Yoon, Y. \& Swales, G. (1990). Predicting Stock Price Performance. Proceeding of the 24th Hawaii International Conference on System Sciences, 4, 156-162.

Yumlu, S., Gurgen, F. \& Okay, N. (2005). A Comparison Of Global, Recurrent and Smoothed-Piecewise Neural Models For Istanbul Stock Exchange (ISE) Prediction. Pattern Recognition Letters, 26, 13, 2093-2103

Zadra, G. (1988). Stock Market Volatility and Financial Crises, Salomon Brothers Center for the Study of Financial Institutions Italian Study Group Symposium,New York University.

Zhang, G., Patuwo, B. E. \& Hu, M. Y. (1998). Forecasting With Artificial Neural Networks: The State of The Art. International Journal of Forecasting, 14, 35-62. 